\title{
Fertility Status of Major Cropping Systems Existing in Black Soils of Mudhol Taluka of Northern Karnataka, India
}

\author{
M.V. Rekha*, E.K. Anita, B.V. Champa, Ashok, S. Alur and M.S. Nagaraja \\ Department of Soil Science and Agricultural Chemistry, University of Horticultural Sciences, \\ Bagalkot - 587 104, India
}

\begin{tabular}{|l|}
\hline K e y w o r d s \\
Soil fertility, Free \\
$\mathrm{CaCO}_{3}$, Vertisols, \\
$\begin{array}{l}\text { Cropping systems, } \\
\text { Soil organic-C }\end{array}$ \\
\hline Article Info \\
\hline $\begin{array}{l}\text { Accepted: } \\
\text { 20 April } 2018 \\
\text { Available Online: } \\
\text { 10 May } 2018\end{array}$ \\
\hline
\end{tabular}

Soil properties are sensitive to changes in the soil environment as influenced by vegetation, climate and inputs and losses of biomass and nutrients. Thus, the cropping systems with different management practices are likely to influence soil properties. Grid based soil survey was conducted in Mudhol to compare the soil fertility status of three major cropping systems namely, sugarcane, groundnut-maize/onion and cereal-pulse systems. Surface composite soil samples representing 143 grids of $4.86 \mathrm{sq} \mathrm{km}$ each were analyzed for available major and secondary nutrients and the factors influencing their availability namely, $\mathrm{pH}$, free $\mathrm{CaCO}_{3}$ and soil organic-C. Among nutrients, available-N, $\mathrm{K}$ and $\mathrm{S}$ varied significantly among three cropping systems while, available-P, $\mathrm{Ca}$ and $\mathrm{Mg}$ did not vary significantly. Variations in soil $\mathrm{pH}$ as influenced by free $\mathrm{CaCO}_{3}$ might have reduced phosphorus availability. The soil organic-C was found positively correlated with $\mathrm{N}$-availability in soils. Higher amounts of nutrient (except K) in irrigated cropping systems especially, sugarcane system may be attributed to nutrient and water management practices and high biomass turnovers. Less utilization of soil-K may be the reason for higher Kavailability in cereal-pulse cropping systems.

\section{Introduction}

Nutrient availability plays an important role in crop production. Availability of nutrients depends on soil, climate, cropping system, management practices etc (Raysschaert et al., 2004). Evaluation of soil fertility thus, serves as one of the most important tool to achieve higher crop yields. Soil tests provide information about nutrient availability upon which the fertilizer recommendations could be made for maximizing crop yields. Maintenance of optimum concentration of plant nutrient in soil has significant agronomic importance, as they are vital to maintain physiological plant functions. The availability of nutrients is very sensitive to changes in soil environment and they are largely influenced by soil organic matter and soil reaction (Lindsay, 1972). These soil properties are directly influenced by native soil properties and crop management practices. This study was conducted systematically for a Taluka (Block) to assess macronutrients availability in black soil and the factors influencing it. 


\section{Materials and Methods}

\section{Study area and the cropping systems}

Field based soil fertility survey was carried out in Mudhol Taluka (Bagalkot District) of Northern Karnataka. The mean annual temperature (last 10 year) of Mudhol Taluka varied from 30.2 to $32.6{ }^{\circ} \mathrm{C}$. The average annual precipitation was about $447.3 \mathrm{~mm}$ and nearly 90 per cent of it was received during monsoon season. The study area was mostly under black soils (> $90 \%$ ) and sugarcane, maize/ groundnut - onion and cereal-pulse crops were the predominant cropping systems. The entire study area of Mudhol was divided into smaller grids of $2.25 \times 2.25 \mathrm{~km}^{2}$ (sq. $\mathrm{km}$ ) and each grid was used as a study unit. The dominant cropping system of each grid was identified and a representative location was identified for soil study.

\section{Soil sampling and analyses}

The soil samples were collected from the above predetermined representative points. Soil samples were collected from 3 different points at $0-15 \mathrm{~cm}$ depth and made into one composite sample. Representative soil samples were air dried, sieved $(2 \mathrm{~mm})$ and stored for fertility analysis.

Processed soil samples were analysed for soil $\mathrm{pH}$ (1:2.5 soil:water ratio) by $\mathrm{pH}$ meter (Model Systronics 361); soil organic matter by wet oxidation method (Walkley and Black, 1934); and free $\mathrm{CaCO}_{3}$ content by acid titration (Richards, 1954). Among major soil nutrients, alkaline potassium permanganate method for available-N (Subbiah and Asija, 1956); ammonium molybdate complex colorometric method for available - $\mathrm{P}_{2} \mathrm{O}_{5}$ (Jackson, 1973) and ammonium acetate extractant - flame photometric method for available $\mathrm{K}_{2} \mathrm{O}$ (Jackson, 1973) were adopted. The secondary nutrients namely, available-Ca and $\mathrm{Mg}$ (exchangeable) and available-S were determined by versenate titration and turbidometric method respectively (Black, 1965).

\section{Statistical analysis}

Finally, these observations were subjected to ANOVA tests for comparison of cropping systems. Correlation tests were also made to assess the influence of $\mathrm{pH}$, free $\mathrm{CaCO}_{3}$ and Soil organic-C contents on nutrient availability.

\section{Results and Discussion}

\section{Availability of major nutrients}

The extent of nitrogen, phosphorus and potassium availability among three different cropping systems are given in Table 1 and their mean values are depicted in Figure 1. Among 143 soil samples analysed, more than $2 / 3^{\text {rd }}$ of the samples $(n=101)$ recorded medium levels of available- $\mathrm{N}\left(280-560 \mathrm{~kg} \mathrm{~N} \mathrm{ha}{ }^{-1}\right)$ while, the remaining samples had $<280 \mathrm{~kg} \mathrm{~N}$ $\mathrm{ha}^{-1}$. None of the soil samples were observed in higher availability ranges (> $560 \mathrm{~kg} \mathrm{~N} \mathrm{ha}^{-1}$ ). Among different cropping systems, the available- $\mathrm{N}$ in sugarcane systems (340.74 \pm $76.68 \mathrm{~kg} \mathrm{~N} \mathrm{ha}^{-1}$ ) and maize /groundnut onion systems $\left(321.96 \pm 57.27 \mathrm{~kg} \mathrm{~N} \mathrm{ha}^{-1}\right)$ were found on par with each other and the mean values were found significantly higher than cereal- pulse system $(286.4 \pm 46.46 \mathrm{~kg} \mathrm{~N}$ $\mathrm{ha}^{-1}$ ). Higher amounts of available-N in sugarcane and maize/ groundnut-onion based cropping systems may be attributed to application of large amounts of $\mathrm{N}$-fertilizers (Kumar et al., 2014). It may also be higher soil organic-C in these soils at it exhibits strong positive relationship with available-N (Pulakeshi et al., 2012).

In terms of available-P, nearly $1 / 3^{\text {rd }}$ of soil samples $(n=46)$ recorded lower availability $(<$ 
$22.9 \mathrm{~kg} \mathrm{P}_{2} \mathrm{O}_{5} \mathrm{ha}^{-1}$ ) while, half of the soil samples $(\mathrm{n}=80)$ were observed with medium range values (22.9-56.3 $\left.\mathrm{kg} \mathrm{P}_{2} \mathrm{O}_{5} \mathrm{ha}^{-1}\right)$. Only $1 / 10^{\text {th }}$ of the samples were found in higher availability range $\left(56.3 \quad \mathrm{~kg} \quad \mathrm{P}_{2} \mathrm{O}_{5} \quad \mathrm{ha}^{-1}\right)$. However, the mean available- $\mathrm{P}_{2} \mathrm{O}_{5}$ contents among different cropping systems did not vary significantly. Minor variations in its availability among different systems may be attributed to phosphorus applications (Freney et al., 1983). Low availability of phosphorus in some soils may be attributed to higher $\mathrm{pH}$. Presence of free $\mathrm{CaCO}_{3}$ is known to have higher activity of calcium in soil solution and induce precipitation of added-P into dicalcium phosphates and Octa-calcium phosphates (Mortvedt et al., 2000).

Nearly $2 / 3^{\text {rd }}$ of the samples $(n=93)$ were recorded in higher potassium ranges $(>336 \mathrm{~kg}$ $\mathrm{K}_{2} \mathrm{O}$ ha $^{-1}$ ) while, $1 / 3^{\text {rd }}$ of the samples showed medium availability range (144-336 $\mathrm{kg} \mathrm{K}_{2} \mathrm{O}$ $\left.\mathrm{ha}^{-1}\right)$. None of the soil samples were observed in lower ranges $\left(<144 \mathrm{~kg} \mathrm{~K}_{2} \mathrm{O} \mathrm{ha}^{-1}\right)$. Among different cropping systems, the available potassium contents varied significantly in the order: cereal-pulse system $(407.01 \pm 44.80 \mathrm{~kg}$ $\mathrm{K}_{2} \mathrm{O}$ ha $\left.^{-1}\right)>$ sugarcane $(357.01 \pm 84.48 \mathrm{~kg}$ $\mathrm{K}_{2} \mathrm{O}$ ha $^{-1}$ ) > maize / groundnut - onion cropping systems $\left(321.86 \pm 90.09 \mathrm{~kg} \mathrm{~K}_{2} \mathrm{O}\right.$ ha ${ }^{-}$ $\left.{ }^{1}\right)$. Inherent abilities of black soils for high $\mathrm{K}$ contents associated with low crop uptake in dry land areas might be the reasons for their higher availability compared to higher uptake in other cropping systems with irrigations (Raysschaert et al., 2004).

\section{Availability of secondary nutrients}

The extent of available secondary nutrient status among different cropping systems is presented in Table 1 and their respective mean values are depicted in Figure 2 . Nearly $3 / 4^{\text {th }}$ of soils of Mudhol taluka were observed with higher available-Ca (> $\left.32.0 \mathrm{meq} 100 \mathrm{~g}^{-1}\right)$ and available-Mg (> 8.0 meq $\left.100 \mathrm{~g}^{-1}\right)$ contents.
However, these nutrient mean values did not differ significantly among three cropping systems studied. The arid conditions prevailing in Mudhol and occurrence of free $\mathrm{CaCO}_{3}$ might have caused higher availability in all the systems. Similar observations on higher $\mathrm{Ca}$ and $\mathrm{Mg}$ contents in Rajasthan are reported (Dhir et al., 1979).

The amount of available sulphur in soils ranged from 5.84 to $55.75 \mathrm{ppm}$. In terms of its availability, nearly $50 \%$ of the soil samples were observed in lower range $(<10 \mathrm{ppm}-\mathrm{S})$. Interestingly, $1 / 3^{\text {rd }}$ of the soil samples from sugarcane cropping system were recorded in higher range (>20 ppm-S). Among different cropping systems, sugarcane $(20.84 \pm 14.76$ ppm-S) and maize / groundnut - onion system (18.01 \pm 14.58 ppm-S) recorded higher sulphur contents compared to cereal - pulse cropping systems (12.05 \pm 6.81 ppm-S). Application of sulphur containing fertilizer nutrients such as $\mathrm{MgSO}_{4}$ and $\left(\mathrm{NH}_{4}\right)_{2} \mathrm{SO}_{4}$ in sugarcane and use of $\mathrm{CaSO}_{4}, \mathrm{MgSO}_{4}$ and elemental-S in maize- ground nut/ onion systems might have caused higher sulphur availability (Balanagoudar and Satyanarayana, 1990).

\section{Factors influencing soil fertility}

The presence of free $\mathrm{CaCO}_{3}$ and Soil organic$\mathrm{C}$ are likely to influence nutrient availability (Rahmatullah et al., 1994). The experimental data indicated a strong positive relationship between soil organic-C and available- $\mathrm{N}$ (Figure $3 ; \mathrm{R}^{2}=0.294 *$ ). The soil organic-C is considered as nutrient store house and it also has complimentary effects by chelation of metal ions (Pulakeshi et al., 2012). Similar reports of higher available- $\mathrm{N}$ among different land use systems with increase in soil organic$\mathrm{C}$ are reported in irrigated cropping systems (Punith Raj et al, 2012). The presence of free $\mathrm{CaCO}_{3}$ showed significant negative effects on available phosphorus $\left(\mathrm{R}^{2}=0.229^{*}\right)$. 
Table.1 Extent of major and secondary nutrient availability among different cropping systems

\begin{tabular}{|c|c|c|c|c|c|c|c|c|c|}
\hline \multirow[t]{3}{*}{ Cropping System } & \multicolumn{9}{|c|}{ Number of samples with different availability ranges $w . r . t}$. \\
\hline & \multicolumn{3}{|c|}{ Nitrogen $\left(\mathrm{kg} \mathrm{N} \mathrm{ha}^{-1}\right)$} & \multicolumn{3}{|c|}{ Phosphorus $\left(\mathrm{kg} \mathrm{P}_{2} \mathrm{O}_{5} \mathrm{ha}^{-1}\right)$} & \multicolumn{3}{|c|}{ Potassium $\left(\mathrm{kg} \mathrm{K}_{2} \mathrm{O} \mathrm{ha}^{-1}\right)$} \\
\hline & $\begin{array}{l}\text { Low } \\
\quad<280\end{array}$ & $\begin{array}{l}\text { Medium } \\
280-560\end{array}$ & $\begin{array}{l}\text { High } \\
\quad>560\end{array}$ & $\begin{array}{l}\text { Low } \\
\quad<22.9\end{array}$ & $\begin{array}{l}\text { Medium } \\
22.9-56.3\end{array}$ & $\begin{array}{l}\text { High } \\
\quad>56.3\end{array}$ & $\begin{array}{l}\text { Low } \\
\quad<144\end{array}$ & $\begin{array}{l}\text { Medium } \\
144 \text { - } 336\end{array}$ & $\begin{array}{l}\text { High } \\
\quad>336\end{array}$ \\
\hline Cereal-Pulse $(n=16)$ & 7 (4.89) & $9(6.10)$ & $\mathbf{0}(\mathbf{0 . 0 0 )}$ & $6(4.19)$ & $10(6.99)$ & $\mathbf{0}(\mathbf{0 . 0 0})$ & $\mathbf{0}(\mathbf{0 . 0 0})$ & $1(0.69)$ & $15(10.48)$ \\
\hline Maize /G nut - Onion $(\mathrm{n}=5)$ & $1(0.69)$ & $4(2.71)$ & $\mathbf{0}(\mathbf{0 . 0 0 )}$ & $2(1.39)$ & $3(2.09)$ & $\mathbf{0}(\mathbf{0 . 0 0})$ & $\mathbf{0}(\mathbf{0 . 0 0 )}$ & $3(2.09)$ & $2(1.39)$ \\
\hline Sugarcane $(n=122)$ & $28(19.58)$ & $94(65.72)$ & $0(0.00)$ & $38(26.56)$ & $67(46.84)$ & 17 (11.80) & $0(\mathbf{0 . 0 0 )}$ & $46(30.92)$ & $76(54.31)$ \\
\hline \multirow[t]{2}{*}{ Total $(n=143)$} & $42(29.37)$ & $101(70.62)$ & $\mathbf{0}(\mathbf{0 . 0 0})$ & $46(32.16)$ & $80(55.94)$ & 17 (11.88) & $\mathbf{0}(\mathbf{0 . 0 0 )}$ & $52(34.96)$ & $93(65.03)$ \\
\hline & \multicolumn{9}{|c|}{ Number of samples with different availability ranges w.r.t. } \\
\hline \multirow[t]{2}{*}{ Cropping System } & \multicolumn{3}{|c|}{ Calcium (meq $100 \mathrm{~g}^{-1}$ ) } & \multicolumn{3}{|c|}{ Magnesium (meq $100 \mathrm{~g}^{-1}$ ) } & \multicolumn{3}{|c|}{ Sulphur $\left(\mathrm{mg} \mathrm{kg}^{-1}\right)$} \\
\hline & $\begin{array}{l}\text { Low } \\
\quad<24.0\end{array}$ & $\begin{array}{l}\text { Medium } \\
24.0-32.0\end{array}$ & $\begin{array}{l}\text { High } \\
\qquad>32.0\end{array}$ & $\begin{array}{l}\text { Low } \\
\quad<6.0\end{array}$ & $\begin{array}{l}\text { Medium } \\
6.0-8.0\end{array}$ & $\begin{array}{l}\text { High } \\
\qquad>8.0\end{array}$ & $\begin{array}{l}\text { Low } \\
\quad<10\end{array}$ & $\begin{array}{l}\text { Medium } \\
10-20\end{array}$ & $\begin{array}{l}\text { High } \\
\quad>20\end{array}$ \\
\hline Cereal-Pulse $(n=16)$ & $\mathbf{0}(\mathbf{0 . 0 0})$ & $1(0.69)$ & $15(10.48)$ & $\mathbf{0}(\mathbf{0 . 0 0 )}$ & $\mathbf{0}(\mathbf{0 . 0 0 )}$ & $16(11.18)$ & $9(6.29)$ & $5(3.49)$ & $2(1.39)$ \\
\hline Maize /G nut - Onion $(\mathrm{n}=5)$ & $\mathbf{0}(\mathbf{0 . 0 0})$ & $3(2.09)$ & $3(2.09)$ & $\mathbf{0}(\mathbf{0 . 0 0})$ & $1(0.69)$ & $4(2.79)$ & $3(2.09)$ & $\mathbf{0}(\mathbf{0 . 0 0})$ & $2(1.69)$ \\
\hline Sugarcane $(n=122)$ & $0(0.00)$ & 33 (23.07) & $88(61.53)$ & $4(2.79)$ & $20(13.98)$ & $98(68.52)$ & $54(37.75)$ & $22(15.38)$ & $46(32.16)$ \\
\hline Total $(n=143)$ & $0(0.00)$ & $37(25.87)$ & $106(74.12)$ & $4(2.79)$ & $21(14.68)$ & $118(82.51)$ & $66(46.15)$ & $27(18.88)$ & $50(34.96)$ \\
\hline
\end{tabular}


Fig.1 Available major nutrient status among different cropping systems
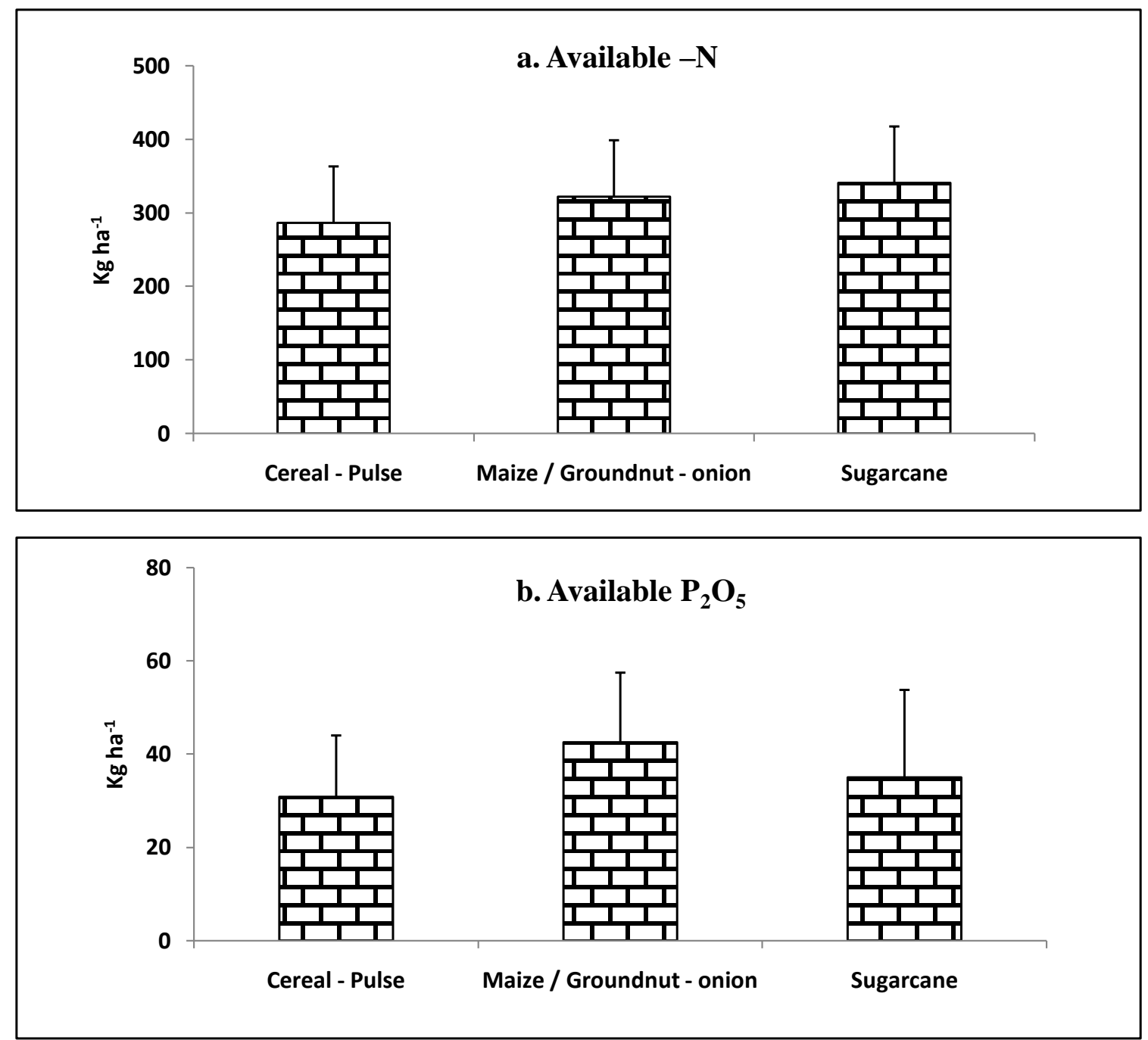

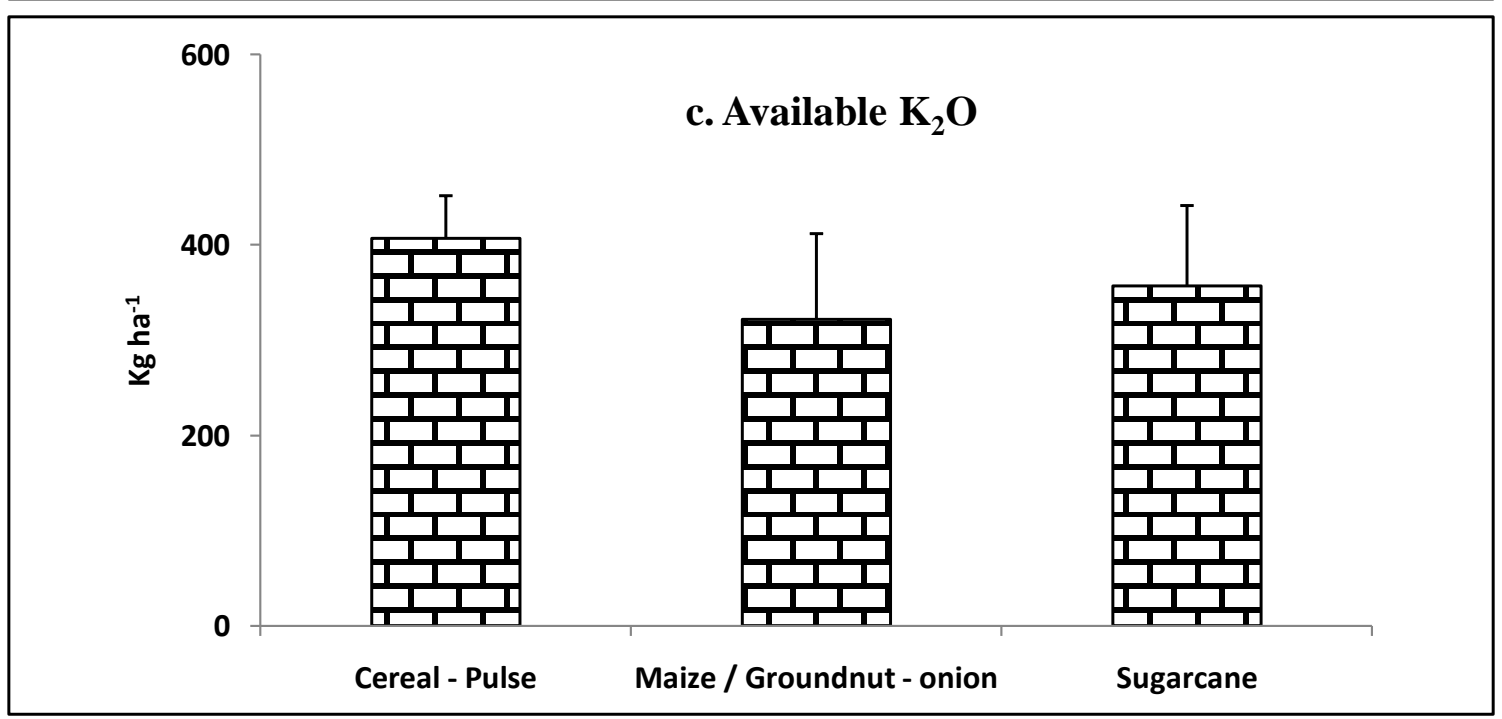


Fig.2 Available secondary nutrient status among different cropping systems
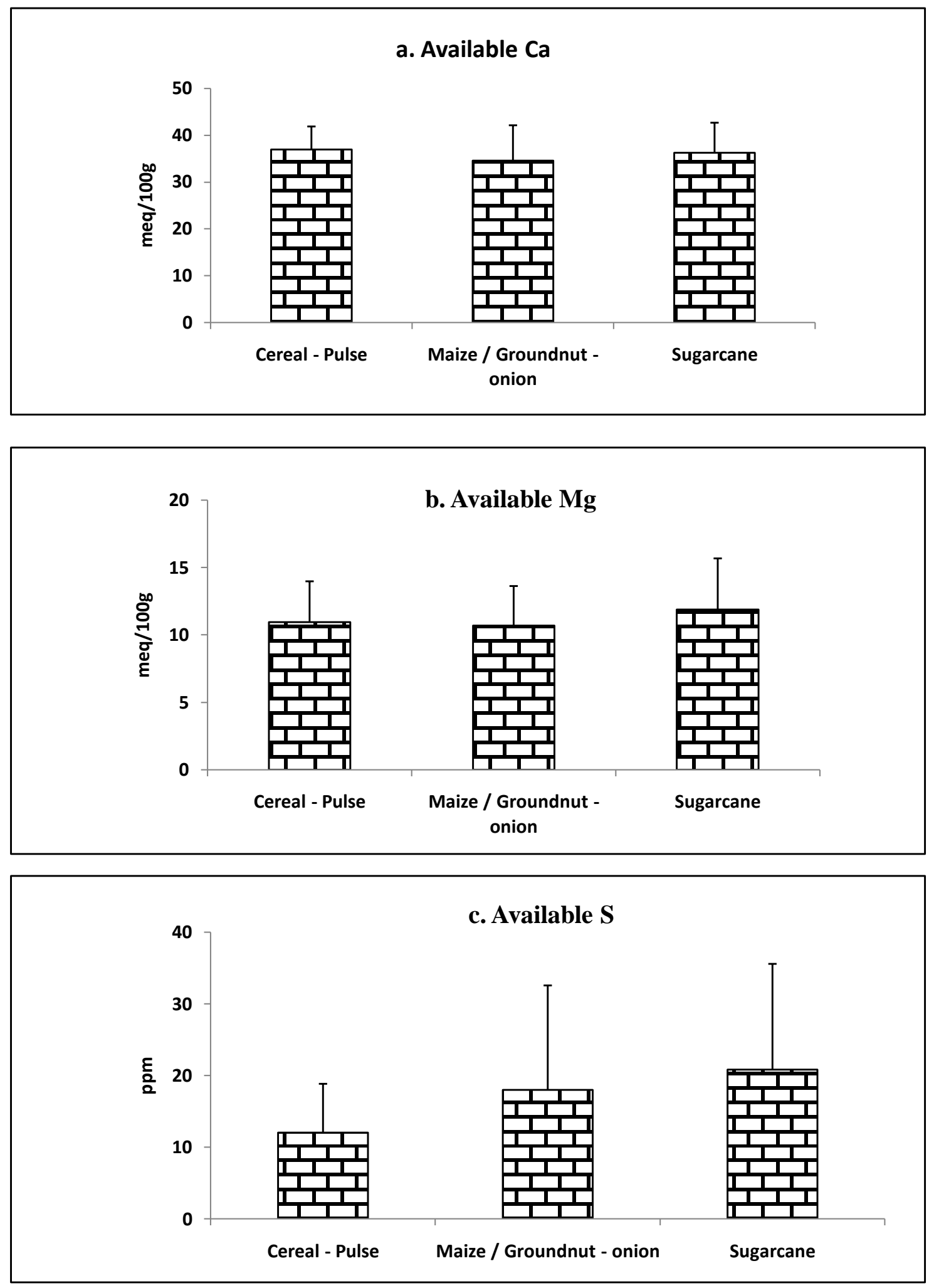
Fig.3 Relationship between a. Soil Organic-C (\%) and available-N (kg/ha) and b. Free $\mathrm{CaCO}_{3}($ in $\%)$ and available- $\mathrm{P}_{2} \mathrm{O}_{5}\left(\mathrm{~kg} \mathrm{ha}^{-1}\right)$

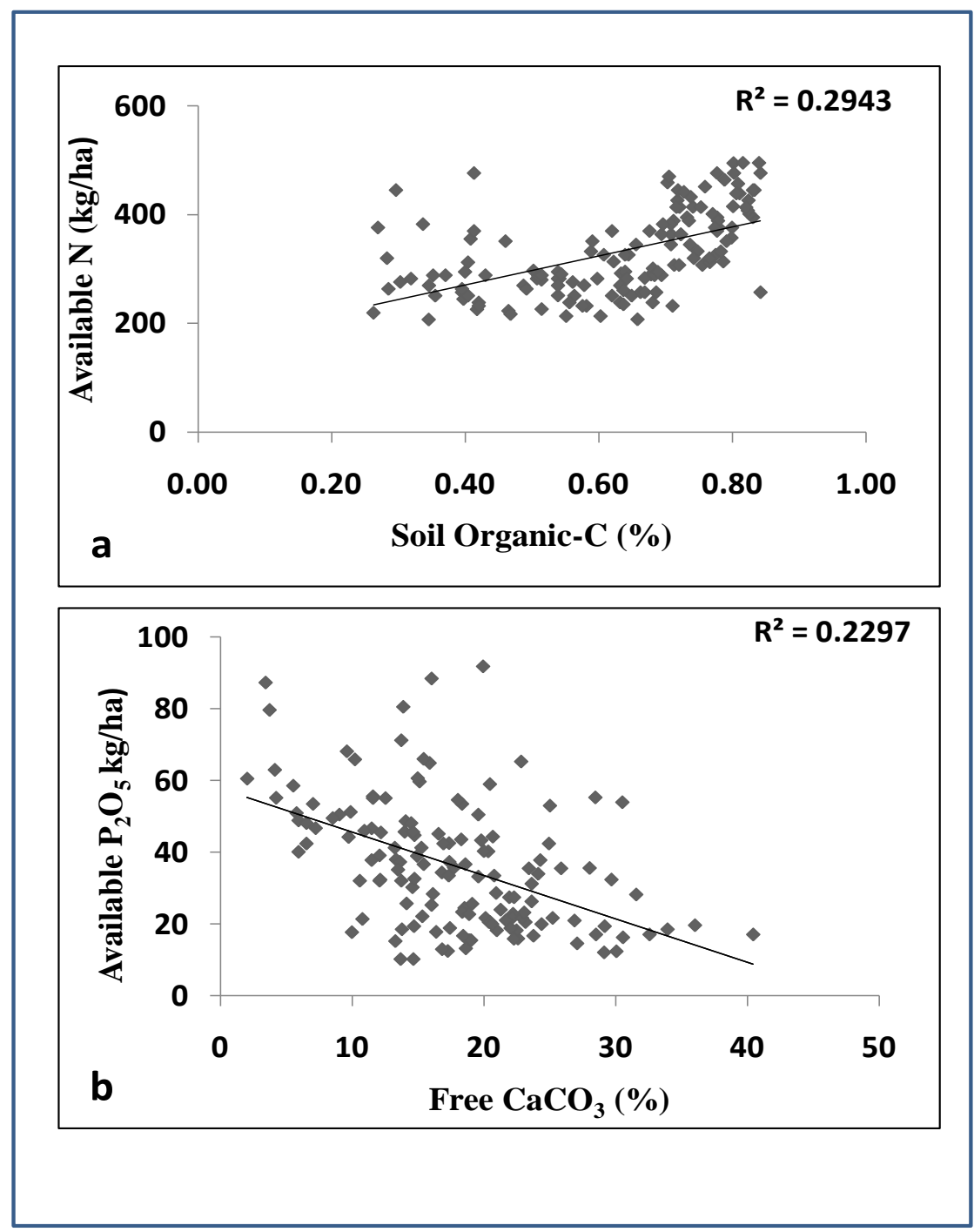

Higher amounts of free $\mathrm{CaCO}_{3}$ are known to increase soil $\mathrm{pH}$ and induce higher Ca-activity and hence, fixation of added phosphorus into insoluble forms (Mortvedt et al., 2000). The study indicated that intensive cropping systems with high biomass turnovers are likely to exhibit higher nutrient availability.

\section{References}

Balanagoudar, S.R. and Satyanarayana, T., 1990. Correlation of different forms of sulphur with soil properties, organic carbon and nitrogen in Vertisols and Alfisols. J. Indian Soc. Soil Sci., 38: 641-645.

Black, C. A., 1965, Methods of Soil AnalysisPart 2, Agronomy monograph No.9, American Society of Agronomy, Madison, Wisconsin, USA, 15-72.

Dhir, R.P., Singh, N. and Sharma, B.K., 1979, Nature and incidence of soil salinity in Pali block, western Rajasthan. Ann. Arid Zone, 18: 27-34.

Freney, I. R., Simpson, J. R. and Denmead, O. T., 1983, Volatilization of ammonia. In 
gaseous loss of nitrogen from plant-soil systems.Dev. Plant Soil Sci., 9: 1-32.

Jackson, M. L., 1973, Soil Chemical Analysis. Prentice Hall of India Pvt. Ltd., New Delhi.

Kumar, A., Mishra, V. N., Srivastav, L. K. and RakeshBanwasi, 2014, Evaluations of soil fertility status of available major nutrients (N, $\mathrm{P}$ and $\mathrm{K})$ and micro nutrients $(\mathrm{Fe}, \mathrm{Mn}, \mathrm{Cu}$ and $\mathrm{Zn}$ ) in vertisol of Kabeerdham district of Chhattisgarh, India. Int. J. Interdiscipl. Multidiscipl. Stud.,1 (10): 72-79.

Lindsay, W.L. 1972. Inorganic phase equilibria of micronutrients in soils. In: micronutrients in Agriculture, J.J. Mortvedt et al., (ed.). Soil Sci. Soc. Am., Madison, Wisconsin, USA. pp. 4157.

Mortvedt, J. J., 2000, Bioavalability of micronutrients; Handbook of soil science- Boca Raton, USA, 71-88.

Pulakeeeshi, H. B. P., Patil, P. L., Dasog, G. S., Radder, B. M., Bidari, B. I. and Mansur, C. P., 2012, Mapping of nutrient status by geographic information system (GIS) in Mantagani village under northern transition zone of Karnataka. Karnataka J. Agric. Sci., 25 (3): 332-335.

Punith Raj, T.S., Nagaraja, M.S., Prabhudev Dhumgond, Sharanbhoopal Reddy,
Shivakumar, K.M., 2012. Soil fertility status of tomato (Lycopersiacon esculentum. Mill) grown areas of Hassan district, Karnataka. An Asian Journal of Soil Science, 7(2): 288-291.

Rahmatullah, M. A., Gill, Sheikh, B. Z. and Saleem, M., 1994, Bio availability and distribution of $\mathrm{P}$ among inorganic fractions in calcareous soils. Arid soil Res. Rehab., 8: 227-234.

Raysschaert, G., Poeson, J.,Versraeten, G. and Govers, G., 2004, soil loss due to crop harvesting; significance and determining factors, Prog. Phys. Geog., 28 (4): 467-501.

Richards, L. A., ed. 1954. Carbonate and bicarbonate estimations by titration with acid, In Diagnosis and Improvement of Saline and Alkali soils. USDA Handbook No. 60, pp 98.

Subbiah, B. V. and Asija, G. L., 1956, A rapid procedure for the estimation of available nitrogen in soil. Curr. Sci., 25: 259-260.

Walkley, A. J. and Black, C. A. 1934.An examination of the method for determining soil organic matter and a proposed modification of the chromic acid titration method. Soil Sci.,37: 2938.

\section{How to cite this article:}

Rekha, M.V., E.K. Anita, B.V. Champa, Ashok, S. Alur and Nagaraja, M.S. 2018. Fertility Status of Major Cropping Systems Existing in Black Soils of Mudhol Taluka of Northern Karnataka. Int.J.Curr.Microbiol.App.Sci. 7(05): 2829-2836. doi: https://doi.org/10.20546/ijcmas.2018.705.328 